Primljen / Received: 24.1.2014. Ispravljen / Corrected: 6.3.2014. Prihvaćen / Accepted: 31.3.2014. Dostupno online / Available online: 10.6.2014.

\section{Modelling of a bridge stay cable for individual strand tensioning}

Authors:

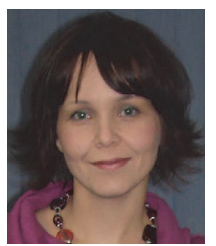

Marija Spasojević-Šurdilović, Ana Spasojević, Dragoslav Stojić

Professional paper

\section{Modelling of a bridge stay cable for individual strand tensioning}

Analytical expressions for determining the required tensioning force in strands, and the corresponding deformation of cables during the multi-cycle tensioning process, are derived in the paper based on the proposed mathematical model of a bridge stay cable. Monostrand jacks are used in this procedure and, at that, strands are tensioned in each cycle by individual application of force of the same intensity. The number of cycles depends on geometrical and mechanical properties of the cable, on the final tensioning force intensity, and on the moveability of the cable support points. The efficiency of the proposed analytical procedure is illustrated by a numerical example.

Key words:

stay cable, strand, cyclic tensioning, tensioning force, cable deformation, monostrand jack

Stručni rad

Marija Spasojević-Šurdilovié, Ana Spasojevié, Dragoslav Stojić

\section{Modeliranje kosog mostovskog kabela za pojedinačno zatezanje užadi}

Dr.sc. Ana Spasojević, PhD. CE

Structural engineering company INGENI SA Genève

University of Applied Sciences and Arts Western Switzerland

ana.spasojevic@ingeni.ch

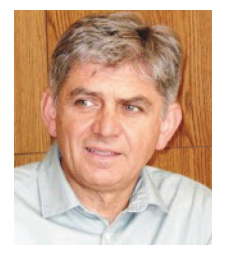

U radu su, na osnovi predloženog matematičkog modela kosog mostovskog kabela, izvedeni analitički izrazi za određivanje potrebne sile zatezanja u užadima i odgovarajuće deformacije kabela pri postupku višecikličnog zatezanja. Za ovaj postupak koriste se lake hidraulične preše (eng. monostrand jacks), pri čemu se u svakom ciklusu užad zateže pojedinačno silom istog intenziteta. Broj ciklusa zavisi od geometrijskih i mehaničkih karakteristika kabela, od intenziteta konačne sile zatezanja, kao i pomaka točaka oslonaca kabela. Efikasnost predloženog analitičkog postupka prikazana je na numeričkom primjeru.

Ključne riječi:

kosi kabel, uže, ciklično zatezanje, sila zatezanja, deformacija kabela, laka hidraulična preša

Fachbericht

Marija Spasojević-Šurdilović, Ana Spasojević, Dragoslav Stojić

\section{Modellierung von Brücken-Schrägseilen zur Vorspannung von Einzelsträngen}

Faculty of Civil Engineering and Architecture dragoslav.stojic@gaf.ni.ac.rs

Aufgrund des vorgeschlagenen mathematischen Models einer Schrägseilbrücke, wird in dieser Arbeit der analytische Ausdruck für die Berechnung der erforderlichen Strangspannkraft und die entsprechende Kabelverformung im mehrzyklischen Vorspannungsvorgang abgeleitet. Monolitzenspannsysteme sind hierbei angewandt, und die Stränge sind in jedem Zyklus einzeln mit Kräften konstanter Intensität angespannt. Die Anzahl der Zyklen hängt von geometrischen und mechanischen Eigenschaften der Kabel, erzielten Spannkräften und Verschiebungen der Befestigungspunkte der Kabel ab. Die Wirksamkeit des vorgeschlagen analytischen Verfahrens ist durch ein numerisches Beispiel veranschaulicht. 


\section{Introduction}

The stay cable tensioning by hydraulic jacks can be operated either by simultaneous tensioning of all strands, or by individual strand tensioning. Relatively heavy hydraulic jacks are used for collective tensioning of all strands, which complicates tensioning process. However, modern technology has enabled the use of extremely light hydraulic jacks (Figure 1) that are applied for individual tensioning of cable strands. Force can be applied to the cable in cycles and, at that, individual strands are tensioned in every cycle by the force of the same intensity. The anticipated force in cable $\left(Z_{k}\right)$ and the corresponding deformation, and shortening of the cable axis $\left(\xi_{k}\right)$, are determined in the bridge design model for a particular construction phase. The authors of the paper have developed the proposed multi-cycle cable tensioning procedure for the construction of a pedestrian bridge over the Nišava River in Niš (Figure 2), where the procedure was successfully applied [1,2].

According to the other cable tensioning procedure, the individual strand tensioning can be operated in one cycle only. In this procedure, known as tas "isotension process", patented by Freyssinet Institute in Paris, the forces of variable intensity are applied from the first strand to the last strand of the cable, so that forces are equalised in all strands at the end of one cycle only $[3,4]$.

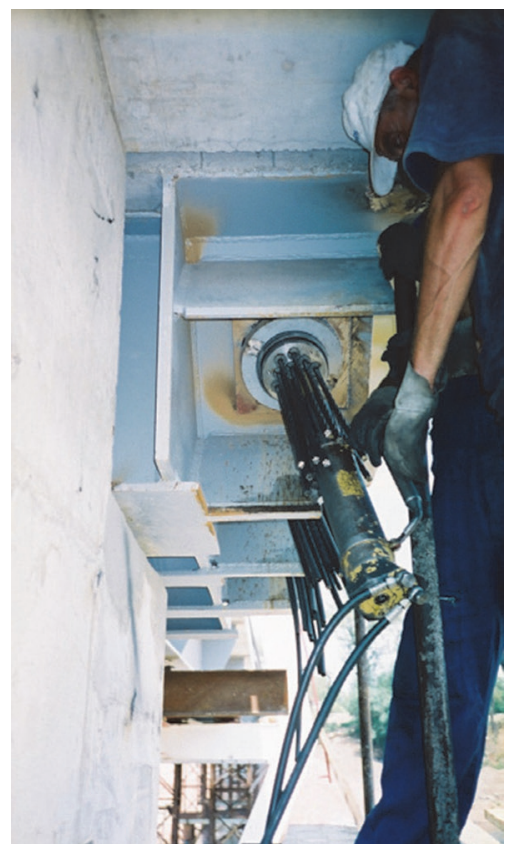

Figure 1 Cable tensioning by monostrand jack

As to materials used for the fabrication of cables, it should be noted that the high strength low-relaxation steel is most often utilised in case of bridges stay cables. Although mechanical properties of steel are continuously improving an especially significant development has been registered in case of complex materials such as carbon fibre strands and this through improvement of their physical properties [5].

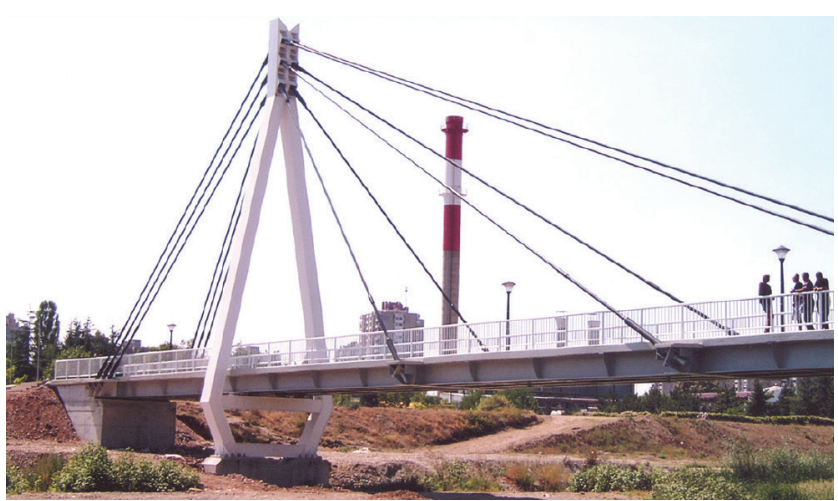

Figure 2. Pedestrian bridge over the Nišava River in Niš

The following basic data are needed for an individual strand tensioning protocol in several cycles:

- coordinates of cable anchoring points, prior to and after tensioning,

- force prior to and after tensioning,

- information about jack and anchors,

- tensioning side (tensioning is conducted from the bottom side, Figure 3),

- information about strands (number, area, mass, elastic modulus), and

- mass of protective pipe and mass of accessory strand for assembly work.

This technological procedure must however be applied with caution. The caution is needed as repeated wedge placing and wedge removal may provoke strand slippage, as in every subsequent cycle the strand elongation is reduced, and so at higher cycles the wedge may come to the already notched part of the strand. In this respect, the one-cycle isotension procedure is obviously more advantageous.

\section{Analytical expressions}

\subsection{General solution for individual tensioning of strands}

Let us consider the stay cable made of $n$ number of equal parallel strands, isolated from the bridge structure (Figure 3), where the system length is described as $I_{\mathrm{K}^{\prime}}$, the cross sectional area of the strand as $A_{u^{\prime}}$ and the elastic modulus as $E_{u^{\prime}}$.

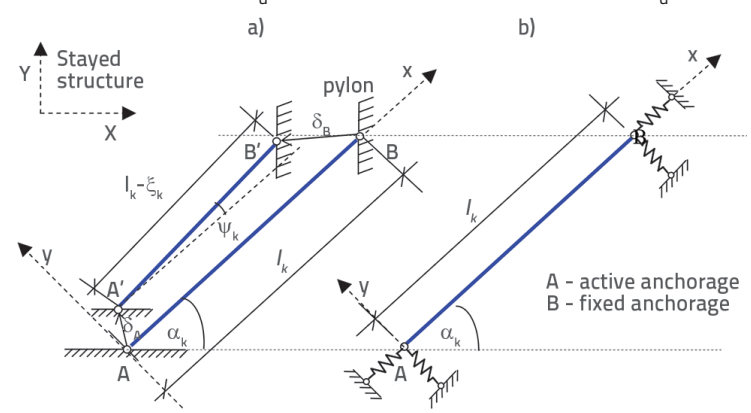

Figure 3. a) Disposition of stay cable prior to and after tensioning; b) mathematical model of isolated cable 
It is assumed that the change in distance between anchoring nodes $A$ and $B$ (Figure 3.a), or shortening $\left(\xi_{k}\right)$ of length of the systemic axis is a linear function of the cable tensioning force $Z_{\mathrm{k}}$. In addition, we consider negligible the difference between the length of the rectilinear cable axis (Figure 3) and the real curved elastic axis, which is a function of deflection, i.e. between the self-weight and inclination of the cable, and the tensioning force $Z_{k}$ [6]. It is also assumed that the cable temperature is constant during the cable tensioning procedure.

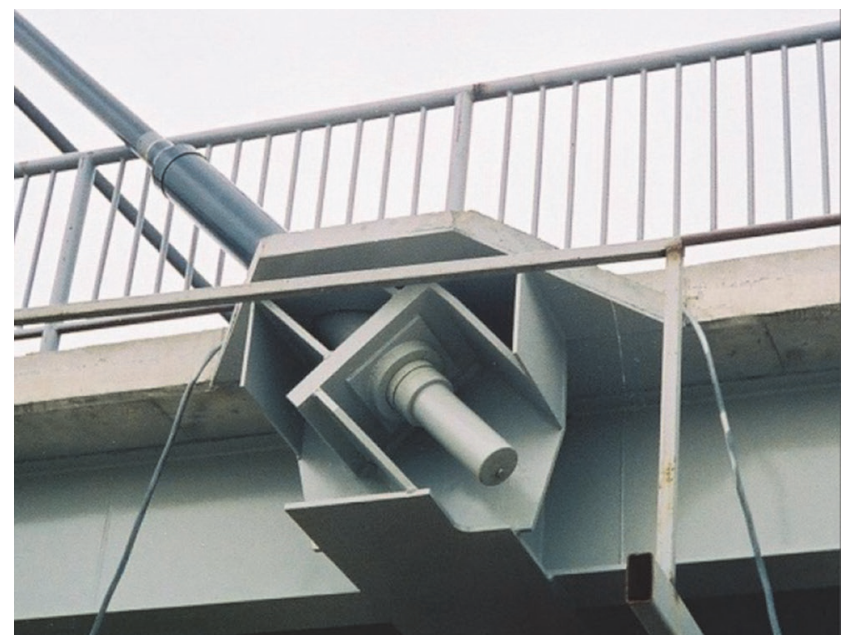

Figure 4. Anchorage block with active anchor

For the influence and self-weight $\left(g_{k}\right)$ of the cable, and after tensioning with the force $Z_{k}$ via the active anchor $A$ (Figures 1 and 4), the supporting tensioning forces in the direction of the cable axis will amount to:

$$
\begin{aligned}
& Z_{A^{\prime}}=Z_{K} \\
& Z_{B^{\prime}}=Z_{K}+g_{k} \cdot\left(I_{k}-\xi_{k}\right) \sin \left(\alpha_{k}+\psi_{k}\right)
\end{aligned}
$$

At the partial tensioning of the stay cable, where stands are tensioned successively, the partial force in cable $\left(\Delta Z_{k, i}\right)$ amounts to:

$$
\Delta Z_{k, i}=Z_{i}-\sum_{j=1}^{i-1} \Delta Z_{j, i} \quad(i=1,2,3, \ldots, n)
$$

where:

$Z_{i} \quad$ - tensioning force applied at the $i$-th strand

$\Delta Z_{j, i} \quad$ - tensioning force drop at the $j$-th strand due to partial shortening of the cable axis after tensioning of the $i$-th strand

The drop of force at the $i$-th strand due to anchoring (wedging) is compensated by adequate increase of the tensioning force, depending on the anchor type.

The total force in cable after the $i$-th strand tensioning amounts to:

$$
Z_{k, i}=\sum_{j=1}^{i} \Delta Z_{k, j}
$$

The partial shortening $\left(\Delta \xi_{k, i}\right)$ of the cable axis after the $i$-th strand tensioning is:

$\Delta \xi_{k, i}=K_{0} \cdot \Delta Z_{k, i}$

and, at that, the total shortening amounts to:

$\xi_{k, i}=\sum_{j=1}^{i} \Delta \xi_{k, j}=K_{0} \cdot Z_{k, i}$

where:

$K_{0}=\frac{\xi_{k, i}}{Z_{k, i}}=\frac{\xi_{k}}{Z_{k}}$

The decrease of the tensioning force $\left(\Delta Z_{j, j}\right)$ in the previously tensioned strands (due to tensioning of the $i$-th strand) is the same for each of these $(i-1)$ strands, and amounts to:

$\Delta Z_{j, i}=\frac{\Delta \xi_{k, i}}{l_{k, i}} \cdot E_{u} \cdot A_{u}$

In expression (8), $I_{k, i}$ is the length of the cable axis prior to tensioning of the $i$-th strand, and amounts to:

$I_{k, i}=I_{k}-\xi_{k, i-1}=I_{k}-K_{0} \cdot Z_{k, i-1}$

which is determined starting from the first strand. At that, for $i=1, I_{k, 1}=I_{\mathrm{k}^{\prime}}$ for $i=2, I_{k, 2}=I_{k}-K_{0} Z_{1}$, etc.

By replacing (8) in (3) and by introducing partial shortening of the cable axis (after shortening of the i-th strand) in (4), the following relationship can be established:

$\Delta \xi_{k, i}=\frac{K_{0} \cdot Z_{i}}{1+(i-1) \eta_{i}}$

where:

$\eta_{i}=\frac{K_{0} \cdot E_{u} \cdot A_{u}}{I_{k, i}}$

By replacing (10) in (8), we obtain:

$\Delta Z_{j, i}=\frac{Z_{i} \cdot \eta_{i}}{1+(i-1) \cdot \eta_{i}}$

By replacing (12) in (3), the partial force in cable can be expressed, after tensioning of the $i$-th strand, by the following relation:

$\Delta Z_{k, i}=\frac{Z_{i}}{1+(i-1) \cdot \eta_{i}}$

The total force in cable after tensioning of the i-th strand $Z_{k, i}=\sum_{j=1} \frac{Z_{j}}{1+(j-1) \cdot \eta_{j}}$

Elongation of the $i$-th strand, after its tensioning and anchoring, amounts to:

$\Delta l_{i}=\frac{Z_{i}\left(I_{k}-\xi_{k, i}\right)}{E_{u} A_{u}}+\Delta \xi_{k, i}$ 


\subsection{Individual tensioning of strands in several cycles}

Tensioning of the stay cable, composed on the $\mathrm{n}$ number of equal parallel strands, can be operated, via the planned force $Z_{k}$ by individual tensioning of strands in cycles. The force $Z_{k}$ and the corresponding deformation $\xi_{k}$ (shortening of cable axis) is determined in the bridge design model for a particular phase of construction.

The force applied in each strand ( $l$ that is tensioned is the same in each cycle and amounts to:

$Z_{i}=\frac{Z_{k}}{n} \quad(i=1,2,3, \ldots, n)$

\subsubsection{First strand-tensioning cycle}

In the first and in every succeeding cycle the strands are tensioned individually using the force of the same intensity. After the end of the first cycle, the forces in strands $Z_{i}^{(1)}$ are non-uniform, and so

$Z_{i}^{(1)}>Z_{i-1}^{(1)},(i=1,2, \ldots, n)$

In the last tensioned strand $Z_{n}^{(1)}$, the force has no losses, and so we have

$Z_{n}^{(1)}=\frac{Z_{k}}{n}$

Partial shortening $\left(\delta \xi_{i}^{(1)}\right)$ of the $i$-th strand due the tensioning of strands $(i+1)$ until $n$, after the first cycle, amounts to:

$\delta \xi_{i}^{(1)}=\xi_{k, n}^{(1)}-\xi_{k, i}^{(1)}$

The drop $\left(\delta Z_{i}^{(1)}\right)$ of the applied force $Z_{i}$ at the $i$-th strand, after the end of the first cycle, amounts to:

$\delta Z_{i}^{(1)}=\frac{\delta \xi_{i}^{(1)}}{I_{k}-\xi_{k, i}^{(1)}} \cdot E_{u} \cdot A_{u}$

At that, the reduced tensioning force of the $i$-th rope amounts to:

$Z_{i}^{(1)}=Z_{i}-\delta Z_{i}^{(1)}$

The relationship (6) is valid for $\xi_{k, i}^{(1)}$ in expressions (19) $i$ (20).

\subsubsection{Higher strand-tensioning cycles}

If the number of cycles is marked with $c$, then the relations for forces and cable deformations can be expressed for the second, third and higher cycles $(c \geq 2)$ based on the corresponding relations defined in Sections 2.1 and 2.2.1. According to relation (10), the partial cable shortening after tensioning of the i-th strand amounts to:

$\Delta \xi_{k, i}^{\left({ }^{(c)}\right.}=\frac{K_{0} \cdot \delta Z_{i}^{(c-1)}}{1+(i-1) \eta_{i}}$ where:

$\eta_{i}=\frac{K_{0} \cdot E_{u} \cdot A_{u}}{I_{k}-\xi_{k, i-1}^{(c)}}$

The total cable shortening in the $c$-th cycle, after tensioning of the $i$-th strand, amounts to:

$\xi_{k, i}{ }^{(c)}=\xi_{k, n}{ }^{(c-1)}+\sum_{j=1}^{i} \Delta \xi_{k, j}{ }^{(c)}=\xi_{k, i-1}{ }^{(c)}+\Delta \xi_{k, i}{ }^{(c)}$

The partial shortening $\left(\delta \xi_{i}^{(c)}\right)$ of the $i$-th strand, due to tensioning of strands $i+1$ ) until $n$, after the $c$-th cycle, amounts to:

$\delta \xi_{i}^{(c)}=\xi_{k, n}{ }^{(c)}-\xi_{k, i}{ }^{(c)}$

The drop $\left(\delta Z_{i}^{(\mathrm{c})}\right.$ ) of applied force $Z_{i}$ in the $i$-th strand, after the end of the c-th cycle, amounts to:

$\delta Z_{i}^{(c)}=\frac{\delta \xi_{i}{ }^{(c)}}{I_{k}-\xi_{k, i}{ }^{(c)}} \cdot E_{u} \cdot A_{u}$

At that, the reduced $\mathrm{i}$-th strand tensioning force amounts to:

$Z_{i}^{(c)}=Z_{i}-\delta Z_{i}^{(c)}$

The factor of tensioning realised in the c-th cycle $\left(\gamma^{(c)}\right)$ must be the same for the cable deformations and forces, in accordance with the following relation:

$\gamma^{(c)}=\gamma_{\xi}^{(c)}=\gamma_{z}^{(c)}$

$\operatorname{In}(28), \gamma_{\xi}{ }_{\xi}^{(c)}$ is the cable axis shortening factor, according to:

$\gamma_{\xi}^{(c)}=\frac{\xi_{k, n}{ }^{(c)}}{\xi_{k}}$

a $\gamma_{\xi}{ }_{\xi}^{(c)}$ is realization factor for the force applied to the cable, in accordance with :

$\gamma_{z}^{(c)}=\frac{Z_{k, n}{ }^{(c)}}{Z_{k}}$

The relation (28) presents the condition of the cable stress and deformation compatibility after the end of tensioning in the i-th cycle.

\section{Numerical example}

The numerical example is given for illustration purposes only. It contains the assumed information (according to Figure 3 ): $I_{k}=60$ $\mathrm{m}, \alpha_{k}=60^{\circ}, \psi_{\mathrm{k}}=2^{\circ}, \mathrm{x}_{\mathrm{k}}=6 \mathrm{~cm}$, and is not related to any real-life bridge. The required data are calculated according to coordinates at the ends, i.e. for cable support points, prior to and after tensioning of strands, based on a global coordinate system of the bridge model adopted in the calculation. According to relations (1) and (2), prior to tensioning, the tensioning force in cable at the active anchor is equal to zero, while it amounts to $9.35 \mathrm{kN}$ at the fixed anchor in the pylon, due to cable weight. After the end of 
tensioning with the design force of $Z_{k}=1200 \mathrm{kN}$, the tensioning force in cable amounts to $1200 \mathrm{kN}$ at the active anchor, while it is $1209.53 \mathrm{kN}$ at the fixed anchor. In this phase, the cable is supported by means of an auxiliary strand, or by other temporary supports (such as scaffolding).

The force at the jack differs from the strand tensioning force under the active anchor for the value of loss that occurs due to wedge insertion during the wedging. For the analysed cable, and for insertion of the wedge with an average design value of $7 \mathrm{~mm}$, the additional force by which the design force in strand (initial force at the jack) is increased amounts to $3.5 \%$ of $Z_{u}=100 \mathrm{kN}$. Characteristics of anchors and strands relating to the studied cable correspond to those of cables forming part of the 'SPB SUPER prestressing system" (developed in the IMS Institute in Belgrade), which was used during construction of the pedestrian bridge over the Nišava River in Niš (Figure 2).

The analysed cable consists of twelve parallel seven-wire strands $16 \mathrm{~mm}$ in nominal diameter. The anchoring at cable ends was conducted using anchors type S 12/16 (normal anchors and fixed anchors). The cable anchoring at pylon head was conducted using a fixed anchor. The cable anchoring in the bridge pavement slab was conducted using a normal (active) anchor through which an individual anchoring of strands is operated.

Materials for the stay cable are sheathed strands type EN10138-3-Y1860 57-16, of low relaxation level (class 2), which are factory-protected with grease and with sheathing made of hard high-density polyethilene. Technical properties of these strands are:

- diameter (steel): $15.7 \mathrm{~mm}$,

- total diameter (steel + grease + HDPE): $19.1 \mathrm{~mm}$,

- area of strand (steel): $A_{u}=150 \mathrm{~mm}^{2}$,

- strand mass (steel + grease + HDPE): $1.29 \mathrm{~kg} / \mathrm{m}$,

- relaxation class: 2 (low relaxation level: <2,5\%),

- characteristic tensile strength: $f_{p k}=1860 \mathrm{~N} / \mathrm{mm}^{2}$

- characteristic failure force: $F_{p k}=A_{u} \cdot f_{p k}=279 \mathrm{kN}$,

- characteristic value of yield force at which permanent $0.1 \%$ elongation occurs: $\mathrm{F}_{\mathrm{p} 0,1}=246 \mathrm{kN}$,

- allowed force in strand (for this specific case): 0,45 $F_{p k}=$ $125,55 \mathrm{kN}$

- elastic modulus: $\mathrm{E}=1,94 \times 10^{5} \mathrm{MPa}$.

The $12 \varnothing 15,7 \mathrm{~mm}$ cable is contained in the HDPE pipe presenting the following properties:

- external diameter of pipe d: $110 \mathrm{~mm}(\Delta \mathrm{d}=+1,0 \mathrm{~mm})$,

- pipe wall thickness s: $6.6 \mathrm{~mm}(\Delta \mathrm{s}=+0,9 \mathrm{~mm})$,

- mass of the HDPE pipe: $2.166 \mathrm{~kg} / \mathrm{m}^{1}$

The basic mass of the cable to be assembled (strands + HDPE pipe) amounts to $12^{-1} 1.29+2.166=17.65 \mathrm{~kg} / \mathrm{m}$. If other cable elements are also taken into account (anchors, caps, distributors, deviators, dampers, vandal resistant steel pipe,

Table 1. First and second tensioning cycles of the individual strand tensioning process

\begin{tabular}{|c|c|c|c|c|c|c|c|c|c|}
\hline \multirow[b]{2}{*}{$\begin{array}{l}\text { Strand } \\
\text { [i] }\end{array}$} & \multirow[b]{2}{*}{$\begin{array}{c}Z_{i} \\
{[\mathrm{kN}]}\end{array}$} & \multicolumn{4}{|c|}{ First tensioning cycle } & \multicolumn{4}{|c|}{ Second tensioning cycle } \\
\hline & & $\begin{array}{c}\Delta \xi_{k, i}^{(1)} \\
{[\mathrm{cm}]}\end{array}$ & $\begin{array}{c}\xi_{k, i}^{(1)} \\
{[\mathrm{cm}]}\end{array}$ & $\begin{array}{l}Z_{k i}^{(1)} \\
{[\mathrm{kN}]}\end{array}$ & $\begin{array}{c}Z_{i}^{(1)} \\
{[\mathrm{kN}]}\end{array}$ & $\begin{array}{c}\Delta \xi_{k, i}^{(2)} \\
{[\mathrm{cm}]}\end{array}$ & $\begin{array}{l}\xi_{k, i}^{(2)} \\
{[\mathrm{cm}]}\end{array}$ & $\begin{array}{l}Z_{k i}^{(2)} \\
{[\mathrm{kN}]}\end{array}$ & $\begin{array}{c}Z_{i}^{(2)} \\
{[\mathrm{kN}]}\end{array}$ \\
\hline 1 & 100 & 0,500 & 0,500 & 100,00 & 76,50 & 0,117 & 5,437 & 1087,46 & 97,49 \\
\hline 2 & 100 & 0,488 & 0,988 & 197,62 & 78,88 & 0,103 & 5,540 & 1108,08 & 97,99 \\
\hline 3 & 100 & 0,477 & 1,465 & 292,97 & 81,20 & 0,090 & 5,630 & 1126,00 & 98,43 \\
\hline 4 & 100 & 0,466 & 1,931 & 386,16 & 83,47 & 0,077 & 5,707 & 1141,40 & 98,80 \\
\hline 5 & 100 & 0,456 & 2,386 & 477,27 & 85,69 & 0,065 & 5,772 & 1154,43 & 99,12 \\
\hline 6 & 100 & 0,446 & 2,832 & 566,40 & 87,87 & 0,054 & 5,826 & 1165,25 & 99,39 \\
\hline 7 & 100 & 0,436 & 3,268 & 653,64 & 89,99 & 0,044 & 5,870 & 1173,98 & 99,60 \\
\hline 8 & 100 & 0,427 & 3,695 & 739,06 & 92,08 & 0,034 & 5,904 & 1180,75 & 99,76 \\
\hline 9 & 100 & 0,418 & 4,114 & 822,73 & 94,12 & 0,025 & 5,928 & 1185,67 & 99,88 \\
\hline 10 & 100 & 0,410 & 4,524 & 904,73 & 96,12 & 0,016 & 5,944 & 1188,85 & 99,96 \\
\hline 11 & 100 & 0,402 & 4,926 & 985,12 & 98,08 & 0,008 & 5,952 & 1190,40 & 100,00 \\
\hline \multirow[t]{2}{*}{12} & 100 & 0,394 & 5,320 & 1063,96 & 100,00 & 0,000 & 5,952 & 1190,40 & 100,00 \\
\hline & & \multicolumn{4}{|c|}{$\gamma^{(1)}=88,66 \%$} & \multicolumn{4}{|c|}{$\gamma^{(2)}=99,20 \%$} \\
\hline
\end{tabular}


Table 2. Third and fourth tensioning cycles of the individual strand tensioning process

\begin{tabular}{|c|c|c|c|c|c|c|c|c|c|}
\cline { 3 - 9 } \multicolumn{2}{c|}{} & \multicolumn{4}{c|}{ Third tensioning cycle } & \multicolumn{3}{c|}{ Fourth tensioning cycle } \\
\hline $\begin{array}{c}\text { Strand } \\
{[\mathrm{i}]}\end{array}$ & $\begin{array}{c}Z_{i} \\
{[\mathrm{kN}]}\end{array}$ & $\begin{array}{c}\Delta \xi_{k, i}^{(3)} \\
{[\mathrm{cm}]}\end{array}$ & $\begin{array}{c}\xi_{k, i}^{(3)} \\
{[\mathrm{cm}]}\end{array}$ & $\begin{array}{c}Z_{k i}^{(3)} \\
{[\mathrm{kN}]}\end{array}$ & $\begin{array}{c}Z_{i}^{(3)} \\
{[\mathrm{kN}]}\end{array}$ & $\begin{array}{c}\Delta \xi_{k, i}^{(4)} \\
{[\mathrm{cm}]}\end{array}$ & $\begin{array}{c}\xi_{k, i}^{(4)} \\
{[\mathrm{cm}]}\end{array}$ & $\begin{array}{c}Z_{k, i}^{(4)} \\
{[\mathrm{kN}]}\end{array}$ & $\begin{array}{c}Z_{i}^{(4)} \\
{[\mathrm{kN}]}\end{array}$ \\
\hline 1 & 100 & 0,013 & 5,965 & 1192,91 & 99,84 & 0,001 & 5,998 & 1199,67 & 99,99 \\
\hline 2 & 100 & 0,010 & 5,974 & 1194,87 & 99,89 & 0,001 & 5,999 & 1199,78 & 100,00 \\
\hline 3 & 100 & 0,007 & 5,982 & 1196,37 & 99,92 & 0,000 & 5,999 & 1199,85 & 100,00 \\
\hline 4 & 100 & 0,006 & 5,987 & 1197,48 & 99,95 & 0,000 & 5,999 & 1199,90 & 100,00 \\
\hline 5 & 100 & 0,004 & 5,991 & 1198,28 & 99,97 & 0,000 & 6,000 & 1199,93 & 100,00 \\
\hline 6 & 100 & 0,003 & 5,994 & 1198,83 & 99,98 & 0,000 & 6,000 & 1199,94 & 100,00 \\
\hline 7 & 100 & 0,002 & 5,996 & 1199,18 & 99,99 & 0,000 & 6,000 & 1199,95 & 100,00 \\
\hline 8 & 100 & 0,001 & 5,997 & 1199,38 & 100,00 & 0,000 & 6,000 & 1199,95 & 100,00 \\
\hline 9 & 100 & 0,000 & 5,997 & 1199,48 & 100,00 & 0,000 & 6,000 & 1199,95 & 100,00 \\
\hline 10 & 100 & 0,000 & 5,998 & 1199,51 & 100,00 & 0,000 & 6,000 & 1199,95 & 100,00 \\
\hline 11 & 100 & 0,000 & 5,998 & 1199,51 & 100,00 & 0,000 & 6,000 & 1199,95 & 100,00 \\
\hline 12 & 100 & 0,000 & 5,998 & 1199,51 & 100,00 & 0,000 & 6,000 & 1199,95 & 100,00 \\
\hline
\end{tabular}

HDPE and steel reducing couplings, etc.) the average cable weight is about $19 \mathrm{~kg} / \mathrm{m}$.

Analytical expressions given in Section 2 were used to calculate forces in strands and in the cable, as well as cable deformations for individual strand tensioning in several cycles. The corresponding results are presented in Tables 1 and 2. After the fourth cycle, elongations of all strands were equal and, according to (15), they amount to $20.5 \mathrm{~cm}$. Consequently, the maximum deflection of the tensioned cable [6] amounts to:

$$
\max _{k} u_{k}=\frac{\left(I_{k}-\xi_{k}\right)^{2}}{8 \times Z_{k}} \times g_{k} \times \cos \left(\alpha_{k}+\psi_{k}\right)=3,2 \mathrm{~cm}
$$

\section{Conclusion}

Modern technology enables the use of extremely lightweight jacks for individual tensioning of cable strands. Force can be applied to the cable in several cycles, in which case the same amount of force is used in each cycle to tension the strands. The number of cycles depends on geometrical and mechanical properties of the cable, on the intensity of the final tensioning force, and on the movability of cable support points (anchors). Analytical expressions proposed in the paper enable simple determination of the number of tensioning cycles, and definition of the force realized in strands as well as the corresponding cable deformations (shortening of the axis), for each cycle. Consequently, the proposed approach is appropriate for controlling the use of technological procedure involving multi-cycle cable tensioning by monostrand jacks, if contractors do not have the equipment needed for "isotension process" [3], which was the case during a pedestrian bridge construction over the Nišava River in Niš, where the proposed procedure was successfully applied.

\section{REFERENCES}

[1] Spasojević-Šurdilović, M.: Modeliranje i analiza stanja napona i deformacija mostova sa kosim zategama pri faznom formiranju sistema pomoću privremenih oslonaca, magistarski rad, Gradevinsko-arhitektonski fakultet, Univerzitet u Nišu, Srbija, 2007. (in Serbian).

[2] Spasojević-Šurdilović, M., Spasojević A., Spasojević, N.: Specifična problematika projektovanja i izvođenja pešačkog mosta preko reke Nišave i Nišu, Treći internacionalni naučno-stručni skup, GNP 2010, Žabljak, Crna Gora, knjiga 1, pp. 643-648, 2010. (in Serbian).

[3] Spasojević-Šurdilović, M., Spasojević, A.: Analytical solutions for determining tension force in strands of bridge stay-cable in isotension procedure, The International Conference Innovation as a Function of Engineering Development-IDE 2011, Faculty of Civil Engineering and Architecture, University of Nis, pp. 319-324, 2011.
[4] Spasojević-Šurdilović, M., Spasojević, A., Prolović, V., Bonić, Z., Davidović, N.: Determination of tension forces in bridge stay cable during successive strand stressing, Treći internacionalni naučno-stručni skup, GNP 2012 - 4th International Conference Civil Engineering - Science and Practice, Žabljak, Crna Gora, pp. 321-328, 2012. (in Serbian).

[5] Radić, J., Kindilj, A., Mandić, A.: Analysis and shaping of cable stay bridges: an example of Jarun Bridge, GRADEVINAR 61 (2009) 9, pp. 837-851. (in Croatian).

[6] Spasojević-Šurdilović, M., Spasojević, A.: Analitička rešenja za deformacije kosih mostovskih kablova, Zbornik radova Građevinsko-arhitektonskog fakulteta u Nišu, 25, pp. 207-214, 2010. (in Serbian). 